\title{
Nazal Septumun Lobüler Kapiller Hemanjiyomu
}

\author{
Lobular Capillary Hemangioma of the Nasal Septum
}

\author{
Gül SOYLU ÖZLER ${ }^{1}$, M. İhsan GÜLMEZ1, Ercan AKBAY ${ }^{1}, \operatorname{Ertap}^{1}$ AKOĞLU ${ }^{1}$ \\ ${ }^{1}$ Mustafa Kemal Üniversitesi, Tip Fakültesi, KBB Anabilim Dalı, HATAY
}

*Bu olgu sunumu 22-26 Mayıs 2014 tarihleri arasında Antalya'da gerçekleştirilen “10.Türk Rinoloji Kongresi”nde poster bildiri olarak sunulmuştur

\begin{abstract}
ÖZET
Pyojenik granulom olarak da isimlendirilen lobüler kapiller hemanjiyom, nazal kavitede nadiren görülür. Lobüler kapiller hemanjiomun etyopatogenezinde hormonal, genetik, mikrobiyolojik ve travmatik birçok mekanizma ileri sürülmüştür. Ayırıc1 tanısinda Kaposi sarkomu, hemanjiyoperisitoma, hemanjiyoendotelyoma, juvenil anjiyofibroma, inverted papilloma, skuamöz hücreli karsinoma ve metastatik maligniteler akılda tutulmalıdır. Tercih edilen uygun tedavi yaklaşımı, endoskopik rezeksiyondur. $\mathrm{Bu}$ olgu sunumunda burun kanaması ile başvuran hastada nadir görülen lobüler kapiller hemanjiyomun ayırıcı tanıda akılda tutulması gerektiği vurgulanmıştır.
\end{abstract}

Anahtar Kelimeler: Nazal kitle, burun kanaması, lobüler kapiller hemanjiyom

\section{GíRIŞ}

Pyojenik granulom olarak da isimlendirilen lobüler kapiller hemanjiyom (LKH), genellikle cilt ve oral mukozadan kaynaklanan, benign fibrovasküler bir lezyondur (1). Tüm yaşlarda görülebilen bu lezyon sıklıkla 3. dekatta ve kadınlarda daha yaygın görülür. Bukkal mukoza, gingiva, dudaklar, dil lobüler kapiller hemanjiyomun en sık görüldüğü bölgelerdir, nazal kavitede nadiren görülür (2). Nazal kavitede görüldüğünde ise genellikle nazal septumdan ve Little alanından kaynaklanır $(3,4)$. En sık karşılaşılan semptomlar aralıklı ve bazen yoğun epistaksise eşlik eden burun tıkanıklığıdır (5).

\section{ABSTRACT}

Lobular Capillary Hemangioma also called as pyogenic granuloma is rarely seen in nasal cavity. Hormonal, genetic, microbiological and traumatic mechanisms are claimed in the etiopathogenesis of Lobular Capillary Hemangioma. Kaposi sarcoma, hemangioperiostoma, hemangioendothelioma, juvenil angiofibroma, inverted papilloma, squamos cell carcinoma and metastatic malignities must be kept in mind in differential diagnosis. The preffered treatment option is endoscopic resection. In this case report, it is emphasized that rarely seen Lobular Capillary Hemangioma must be kept in mind in differential diagnosis in patients presenting with epistaxis

Keywords: Nasal mass, epistaxis, lobular capillary hemangioma

LKH'un etyopatogenezinde hormonal, genetik, mikrobiyolojik ve travmatik birçok mekanizma ileri sürülmüştür $(3,6)$. Ayırıcı tanısında Kaposi sarkomu, hemanjiyoperisitoma, hemanjiyoendotelyoma, juvenil anjiyofibroma, inverted papilloma, squamöz hücreli karsinoma ve metastatik maligniteler akılda tutulmalıdır $(7,8)$.

Tercih edilen uygun tedavi yaklaşımı, endoskopik rezeksiyondur. $\mathrm{Bu}$ olgu sunumunda nazal septum kaynaklı LKH olgusu klinik bulgular ve ayırıcı tanılar eşliğinde tartışılacaktır. 


\section{OLGU}

Otuz iki yaşında kadın hasta üç aydır olan sol tarafta burun tıkanıklığ 1 ve ara sıra burun kanaması nedeniyle diş merkeze başvurmuştur. Hastaya diş merkezde operasyon planlanmış ancak operasyon öncesi lokal anestezi esnasında başlayan masif burun kanaması nedeniyle hastaya anterior tampon uygulanarak kliniğimize yönlendirilmiştir. Hastaya genel anestezi altında anterior tamponlar çıkarıldıktan sonra yapılan nazal muayenede sol nazal kavitede $3 \times 2 \mathrm{~cm}$ boyutlarında, düzensiz yüzeyli, etrafında nekrotik doku bulunan, pembe-mor renkli, septum ile orta konka arasında yerleşmiş irregüler geniş tabanlı kitle izlendi. Bilgisayarlı tomografide (BT) sol nazal kavite anterior kesimde nazal kaviteyi oblitere eden yumuşak doku lezyonu görüldü. Bu lezyonunun nazal septumu sağa doğru deviye ettiği ve orbita medial duvarında minimal erozyona yol açtığı görüldü (Şekil 1). Kitle mukoperikondrium ile birlikte septumdan sıyrılarak 3 mm güvenlik sınırı bırakılarak total eksize edildi. Septal kıkırdak salim görünümdeydi ancak 15 numara bistüri ile lezyonun oturduğu mukozaya komşu septal kıkırdak bir miktar traşlandı. Oluşan defekt sekonder iyileşmeye bırakıldı. Operasyon esnasında ciddi bir kanama olmadi. Hastaya anterior tampon uygulanarak operasyon sonlandırıldı. Nazal tampon iki gün sonra çıkarıldı.

Kitlenin histopatolojik incelemesinde çok katlı yassı epitel ile örtülü ve çoğunluğu lenfosit ve plazma hücrelerinden oluşan kronik enflamatuar hücre infiltrasyonu gösteren lezyonda, ince duvarlı, endotelle döşeli dilate/kavernöz damar yapıları izlendi ve sonucu lobüler kapiller hemanjiyom olarak bildirildi (Şekil 2). Hastanın cerrahiden sonraki 3. ayda yapılan muayenesinde nüks saptanmadı. Hastadan uygulanacak tedavi ve mevcut verilerin bilimsel amaçlı kullanılabileceğine dair onam alındı.

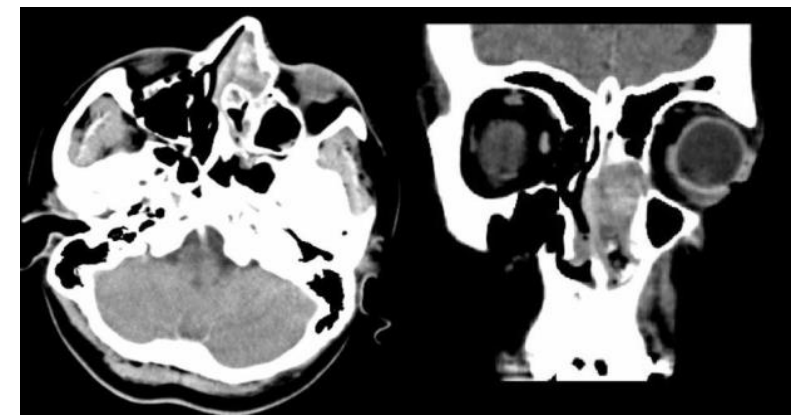

Şekil 1- Aksiyel ve koronal BT görüntüsü. Sol nazal kaviteyi oblitere eden, nazal septumu sağa doğru deviye eden ve orbita medial duvarında minimal erozyona yol açan yumuşak doku lezyonu

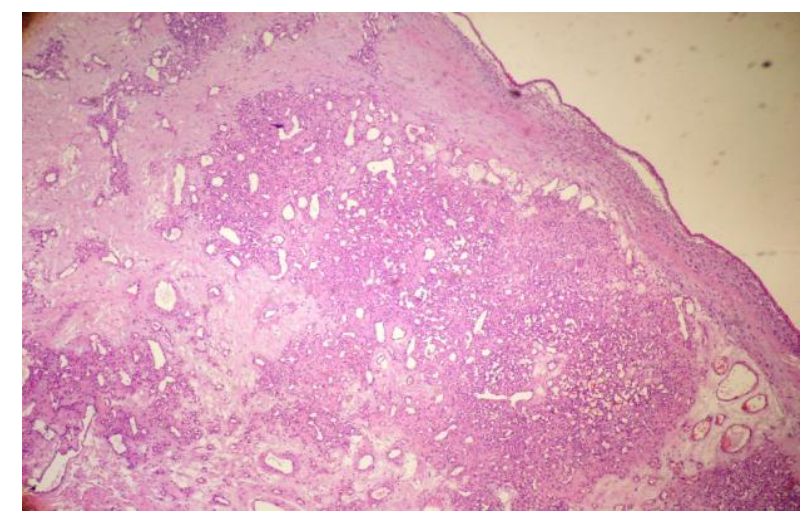

Şekil 2- Hiperplastik çok katlı yassı epitel ile örtülü, kronik inflamatuar hücre infiltrasyonu ve vasküler proliferasyon (hemotoksilen eozin boyama,100'lük büyütme)

\section{TARTIŞMA}

Nazal kavite, hemanjiomların en nadir olarak kaynaklandığı yerlerden biridir. Literatürde bugüne kadar 100 civarında olgu bildirilmiştir. Burundaki hemanjiyomların çoğu kapiller tiptedir ve nazal LKH'ların \%58-80'i anterior nazal septumdan kaynaklanırlar (7,8). Hızla büyüme özellikleri nedeniyle haftalar içinde semptomatik hale gelirler $(3,8)$. Her yaşta ve her iki cinste görülebildiği gibi en sık bayanlarda ve üçüncü dekatta rastlanmaktadır (2).

Bizim olgumuzda 32 yaşında bayan hasta idi. Şikâyetleri 3 ay içerisinde ortaya çıkmıştı ve kitle nazal septum kaynaklıydı. 
En sık rastlanan semptomu, nazal obstrüksiyonun eşlik ettiği aralıklı epistaksistir, ancak pürülan akıntı da eşlik edebilir $(2,8)$. LKH'lar polipoid görünümlü, geniş tabanlı, frajil, mor-kırmızı renkli kitlelerdir. Genellikle nekrotik dokular ve pürülan sekresyonla çevrelenirler $(3,7)$. Şüpheli olgulardan beklenmeyen kanamalara müdahale edilebilecek bir ortamda preoperatif biyopsi alınmalıdır. LKH'den dikkatle yapılan biyopsiler ciddi kanamalara yol açmazlar (7,8). LKH'nin tedavisi cerrahidir. Cerrahi teknik kitlenin yerine göre farklılık gösterir. Lateral duvardan kaynaklanan lezyonlar için tercih edilen teknik lateral rinotomi yaklaşımıdır (9). Ancak, nazal septumdan kaynaklananlar için hemitransfiksiyon veya Killian insizyonu ile direkt eksizyon veya endoskopi yardımıyla çıkarma gibi teknikler kullanılmaktadır $(3,7,8)$. Bizim olgumuzda da, hemitransfiksiyon insizyonunun total rezeksiyon için yeterli görüş sağladığı kanaatindeyiz. Histolojik olarak LKH, prolifere, lobüler yapılar oluşturan endotel hücrelerinden oluşur. $\mathrm{Bu}$ proliferasyonun etyolojisi hala bir miktar tartışmalıdır. Minör travmaya aşırı yerel doku reaksiyonu, hormonal stimülasyon ve viral enfeksiyonlar en sik sorumlu tutulan faktörlerdir $(3,10)$. Ekstranazal LKH'nin çoğunlukla oral mukoza, eller, ayaklar ve dudaklar gibi kronik travmaya maruz kalan yerlerde görülmesi de travma teorisini desteklemektedir (10). Bizim hastamızın öyküsünde travma, lokal irritasyona sebep olabilecek herhangi bir intranasal ilaç kullanımı, viral enfeksiyon, gebelik veya oral kontraseptif kullanımı gibi hormonal değişime sebep olabilecek bir durum yoktu. Cerrahi eksizyon sonrası nüks oranı LKH'larda düşüktür $(6,8)$. Olgumuzda tanı ve tedavi amaciyla total eksizyonu tercih ettik. Hastanın postoperatif üç aylık takibinde nüks saptamadik.

$\mathrm{Bu}$ olgu sunumunda burun kanaması ile başvuran hastada nazal kavitede nadir görülen lobüler kapiller hemanjiyom olgusu sunulmuş olup, nazal kavitede yer kaplayan kitle ayırıcı tanısında göz önünde bulundurulması gerektiği vurgulanmıştır.

\section{KAYNAKLAR}

1. Edalı N. Kan damarı hastalıkları. Temel Patoloji. İkinci bask1. İstanbul: Nobel \& Yüce; 1995: 301.

2. Genç S, Sürkçüoğlu S, Karabulut K, Acar B, Tunçel U, Degerli S. Giant Lobular Capillary Hemangioma of the Nasal Septum. Turk J Med Sci. 2009; 39: 325-8.

3. Rallis E, Balatsouras D, Homsioglou E, Karapantzos I, Danielidis V. Lobular capillary hemangioma of the nasal cavity. J Otolaryngol. 2005; 34(3): 194-5.

4. Puxeddu R, Berlucchi M, Ledda GP, Parodo G, Farina D, Nicolai P. Lobular capillary hemangioma of the nasal cavity: A retrospective study on 40 patients. Am J Rhinol. 2006; 20(4): 480-4.

5. Patrice SJ, Wiss JB, Mulliken JB. Pyogenic Granuloma (Lobular Capillary Haemangioma): A Clinicopathologic study of 178 cases. Pediatr Dermatol. 1991; 8(4): 267-76.

6. Truss L, Dobin SM, Donner LR. Deletion (21)(q21.2q22.12) as a sole clonal cytogenetic abnormality in a lobular capillary hemangioma of the nasal cavity. Cancer Genet Cytogenet. 2006; 170(1): 69-70.

7. Lazar CC, Costentin B, François A, Marie JP, Dehesdin D. "Bleeding poyp" of the nasal septum: An uncommon lesion in adults. Ann Otol Rhinol Laryngol. 2004; 113(8): 652-4.

8. Bizakis J, Nikolidakis A, Panayiotides J, Chimona T, Kyrmizakis D, Helidonis E. Vascular tumors of the nasal Septum. J Otolaryngol. 2002; 31(3): 1702.

9. Dettelbach MA, Weissman JL, Singh J, Eibling DE. "Bleeding polyp" of the osseous nasal septum: A rarely seen lesion. Am J Otolaryngol. 1995; 16(5): 341-6.

10. Kapadia SB, Heffner DK. Pitfalls in the histopathologic diagnosis of pyogenic granuloma (Histological review). Eur Arch Otorhinolaryngol. 1992; 249(4): 195-200. 